\title{
KUASA WACANA DAN DIALOGIS TOKOH “AKU” \\ DALAM LE DERNIER JOUR D'UN CONDAMNÉ
}

\author{
Hendra Kaprisma \\ Fakultas IImu Pengetahuan Budaya Universitas Indonesia \\ kaprisma@ui.ac.id
}

\begin{abstract}
Abstrak
Artikel ini membahas karya dari Victor-Marie Hugo yang berjudul Le dernier jour d'un condamné 'Hari Terakhir Seorang Terpidana Mati' (1829). Novel ini mengisahkan seorang terpidana mati (tokoh "Aku") yang mengalami pergulatan batin mengenai keinginannya untuk bebas. Kuasa wacana dan dialogis yang dilakukan tokoh Aku dalam novel merupakan fokus analisis dalam tulisan ini. Konsep kuasa wacana mengacu kepada pemikiran Michel Foucault dan konsep dialogis diadopsi dari Mikhail Bakhtin. Melalui kedua konsep tersebut, kajian ini berusaha membongkar ide-ide tersembunyi sebagai kritik sosial yang dipaparkan oleh tokoh Aku di dalam novel Hari Terakhir Seorang Terpidana Mati. Berbagai untaian kata yang menggambarkan kegelisahan tokoh Aku seakan membentuk dialog antara teks dan pembacanya. Tokoh Aku mengungkapkan carutmarut kebimbangan pemikirannya akan kebebasan dengan menyajikan teks-teks yang berusaha melakukan tanya-jawab. Dalam hal ini, pembaca sastra diajak untuk turut mengambil bagian dalam pergulatan pemikiran tokoh Aku mengenai kebebasan dirinya. Tarung makna wacana kebebasan yang bergulat dalam pemikiran menjadi syarat terbentuknya dialog antara pembaca dan teks. Oleh karena itu, perspektif dialogis membuatnya teks sastra bersifat sosial sehingga wacana tidak terisolasi dalam struktur.

Kata Kunci: dialogis, kekuasaan, sastra, wacana

\section{Abstract}

This article discusses the work of Victor-Marie Hugo entitled Le dernier jour d'un condamné " (1829). This novel tells about a death row inmate (the "I" character) who experiences an inner struggle about his desire to be free. The power of discourse and dialogue carried out by the character in the novel is the focus of analysis in this paper. The concept of power of discourse refers to Michel Foucault's thoughts and dialogical concepts adopted from Mikhail Bakhtin. This study seeks to dismantle hidden ideas as social criticism presented by the "l" character. The words that describe the anxieties of "I" seem to form a dialogue between the text and the reader. Literary readers are invited to take part in the struggle of my character's thinking about his freedom. The meaning dispute of freedom discourse that wrestles in thought becomes a condition for the formation of dialogue between the reader and the text. Therefore, the dialogic perspective makes a social literary text so that the discourse is not isolated in structure.
\end{abstract}

Keywords: dialogic, discourse, literature, power

\section{A. PENDAHULUAN}

"A monstrous aberration in literary history" (Blackmore 2004: xiv), demikianlah sebutan untuk penulis besar Perancis, Victor-Marie Hugo. Dia anak ketiga dan anak laki-laki terakhir dari pasangan Léopold Sigisbert Hugo (1773-1828) dan Sophie
Trébuchet (1772-1821); saudaranya bernama Abel Joseph Hugo (1798-1855) dan Eugène Hugo (1800-1837). Dia lahir pada 26 Februari 1802 di Besançon dan meninggal pada 22 Mei 1885. Hubungan antara pemerintah Perancis dengan Hugo tidaklah berjalan baik. Dia mengalami pengasingan pada masa pemerintahan Louis-Napoléon 
Bonaparte. Pada 2 Desember 1851, Presiden Republik Perancis, Louis-Napoléon Bonaparte, memiliki kekuasaan penuh dalam suatu coup d'état. Dalam statistik masa pemerintahannya diperkirakan 380 orang terbunuh, 26.642 orang ditahan, dan 9.769 orang dideportasi (Blackmore 2004: xi). Hugo tinggal di Brussel pada 1851, di Jersey dari 1852 sampai 1855, di Guernsey dari 1855 sampai 1870 dan kembali lagi pada 1872 hingga 1873.

Berdasarkan riwayat kepengasingan, periodisasi kepengarangan Hugo dapat dibagi menjadi Sebelum Pengasingan I (1824-1843), Sebelum Pengasingan II (1843-1851), Masa Pengasingan (1851-1870), Setelah Pengasingan I (1870-1878), dan Setelah Pengasingan II (18781885). Salah satu karya Hugo yang akan peneliti analisis adalah Le dernier jour d'un condamné 'Hari Terakhir Seorang Terpidana Mati' (1829). Novel ini sudah dialih bahasakan (versi Bahasa IndonesiaPerancis) oleh M. Lady Lesmana, Hari Terakhir Seorang Terpidana Mati (2005). Novel ini mengisahkan seorang terpidana mati yang mengalami pergulatan jiwa mengenai keinginannya untuk bebas. Hugo melibatkan pembaca dalam pertimbangan yang luar biasa terhadap dampak mengerikan dari eksekusi yang akan datang untuk sang protagonis - tidak hanya pada dia, tetapi pada keluarga dan masyarakatnya juga (Barnet, 2010: 247). Tokoh "Aku" dalam novel diceritakan sebagai seorang laki-laki yang memiliki seorang ibu, seorang istri, dan seorang putri (Marie). Penceritaan dimulai dengan latar penjara Bicêtre dan perkataan Condamné à mort! 'Dihukum mati!' (Hugo 2005: 1). Kisah diawali oleh pengadilan perkara yang dilakukan tokoh Aku di bulan Agustus (hlm. 2) dan ditutup dengan pelaksanaan hukuman mati pada pukul empat (hlm. 100).

Kuasa wacana dan dialogis yang dilakukan tokoh Aku dalam novel merupakan fokus perhatian peneliti dalam tulisan ini. Konsep kuasa wacana mengacu kepada pemikiran Michel Foucault (19261984) dan konsep dialogis diadopsi dari Mikhail Bakhtin (1895-1975). Melalui kedua konsep tersebut, penelitian ini berusaha membongkar ideide tersembunyi sebagai kritik sosial yang dipaparkan oleh tokoh Aku di dalam novel Hari Terakhir Seorang Terpidana Mati.

\section{B. KUASA WACANA FOUCAULT DAN DIALOGIS BAKHTIN}

Foucault merupakan pelopor teori wacana naratif dalam kaitannya dengan ideologi kekuasaan. Menurut Foucault, selama tiga abad masyarakat Barat telah membuat berbagai kesalahan besar, di antaranya: 1) menganggap bahwa pengetahuan objektif dapat diungkapkan, 2) pengetahuan objektif bersifat netral (bebas nilai), 3) pengetahuan objektif dapat memberikan manfaat bagi seluruh umat manusia. Foucault (1998: 17-20) memusatkan perhatian pada pergeseran-pergeseran fundamental yang terjadi dari zaman ke zaman, bukan generalisasi periode. Mekanisme itu yang kemudian menampilkan "arsip" kebudayaan, yang didefinisikan sebagai seperangkat wacana atau teks yang diungkapkan secara actual, perangkat yang befungsi secara terus-menerus dan ditranformasikan melalui kompetensi sejarah-yang sekaligus memberikan kemungkinan bagi kehadirannya kembali di dalam wacana-wacana yang lain (Selden dan Widdowson 1993: 158-159).

Wacana adalah kumpulan pernyataanpernyataan yang ditulis, diucapkan, dikomunikasikan dengan menggunakan tanda-tanda. Di dalam sebuah novel, wacana itulah yang kemudian membentuk citra mengenai tokoh-tokoh, tempat dan waktu kejadian, topik penceritaan, jalinan peristiwa, dan keindahan bahasa sehingga pembaca dapat mengenalinya sebagai penokohan, latar, tema, plot, dan stilistika. Ketika wacana dilahirkan, maka sesungguhnya wacana itu telah dikontrol, diseleksi, diorganisasi, dan didistribusikan kembali menurut kemauan pengarangnya. Wacana tersebut juga dikonstruksi berdasarkan aturan tertentu (Foucault 1998: 18). Oleh karena itu, Foucault menyatakan bahwa kebenaran memiliki mata rantai dengan kekuasaan (O'Farrell 2005: 96).

Selain konsep kuasa wacana, konsep dialogis dari Bakhtin menjadi alat bantu dalam membedah ide-ide tersembunyi tokoh Aku yang terdapat di novel Hari Terakhir Seorang Terpidana Mati. 
Menurut Bakhtin (1999), bahasa adalah gejala sosial, kata-kata merupakan tanda-tanda kemasyarakatan yang aktif dan dinamis sehingga dapat menampilkan arti dan konotasi yang bermacam-macam untuk kelas-kelas yang berbeda. Bakhtin tidak memandang karya sastra sebagai refleksi masyarakat secara langsung, melainkan dinamika bahasa dinyatakan dalam tradisi sastra tertentu. la tidak hanya membicarakan cara-cara teks dalam merefleksikan masyarakat, tetapi bagaimana bahasa mengganggu otoritas sosiokultural sehingga perkembanganbiakan makna dapat dipertahankan. Konsep yang dipaparkan Bakhtin meliputi dialogis, polifonik, karnavalisasi, chronotope, dan wacana novelistik (Holquist 2002; Gardiner 1992).

Karya Bakhtin (1999) yang cukup terkenal adalah pembahasan mengenai novel Dostoevsky yang menyajikan bentuk dialogis atau polifonik. Tokoh-tokoh dalam penceritaan novel itu mempertahankan integritas dan kebebasannya masing-masing. Teks tersebut-sebagai kesimpulan dari analisis Bakhtin-bukanlah teks monologis yang memiliki logika tunggal, homogen, dan relatif seragam sehingga mudah masuk dalam kerangka ideologi tertentu. Dengan demikian, Bakhtin memanfaatkan pengertian dialogis sebagai ciri khas wacana dan dikaitkan dengan ciri prosa novelistik.

Perspektif dialogis Bakhtin merupakan salah satu cara yang menarik untuk memahami kompleksitas struktur karya seni, khususnya sastra. Konsep dialogisme Bakhtinian harus dipertimbangkan terkait hubungannya dengan bahasa itu sendiri (Shirkhani, 2015: 514). Gagasan dialogis dimaksudkan untuk menjelaskan jaringan "suara" yang timbul sebagai aktivitas dialogis. Dialogis dianggap sebagai ciri khas suatu wacana. Kata-kata tidak hanya menampilkan makna, namun menampilkan hubungannya dengan teks lain. Dalam hal ini, karya sastra dianggap sebagai ekspresi polivalensi, narasi dengan dimensi-dimensi bivokal, karya dengan kata-kata yang sudah dihuni oleh suara-suara lain (Holquist 2002: 65-66). Oleh karena itu, tidak ada wacana yang terisolasi, semuanya dialogis karena bahasa bersifat sosial.

\section{KUASA WACANA DAN DIALOGIS TOKOH "AKU"}

Di dalam novel Hari Terakhir Seorang Terpidana Mati diceritakan seorang tokoh "Aku". Tokoh tersebut adalah tokoh utama-dilihat dari intensitas pemunculannya di dalam novel-yang membangun penceritaan. Bicêtre merupakan latar pembuka di dalam novel. Di penjara tersebut tokoh Aku mengawali kisahnya. Keinginan untuk bebas merupakan harapan yang senantiasa menyelimuti kegundahan hatinya menjelang hari-hari pelaksanaan hukuman mati.

"Dulu, sebab bagiku rasanya telah bertahuntahun daripada beberapa minggu, aku adalah manusia bebas, seperti manusia lainnya. Setiap hari, setiap jam, setiap menit mempunyai gagasan. Jiwaku yang muda dan kaya penuh dengan angan-angan. Secara iseng, jiwaku sering menanyakan anganangan itu kepadaku satu demi satu, tanpa urutan dan tanpa akhir, menyulam arabesk yang tidak ada habisnya di kain kehidupan kasar dan tipis ini. Angan-angan tentang gadis-gadis, jubah uskup, pertempuranpertempuran yang dimenangkan, teater penuh suara dan cahaya, lalu gadis-gadis lagi dan jalan-jalan di malam hari yang suram di bawah lengan-lengan raksasa pohon-pohon sarangan. Dalam bayanganku, itu selalu merupakan hari raya. Aku bisa memikirkan apa yang kuinginkan, aku bebas." (Hugo 2005: 1).

Bebas adalah kata yang selalu dipikirkan oleh tokoh Aku. Wacana mengenai kebebasan memenuhi alur penceritaan. Tokoh Aku mengalami kebimbangan yang luar biasa ketika dia dihadapkan dengan kerja paksa seumur hidup, ketakutan akan kematian, dan kerinduan akan putri kecilnya, Marie. Pada awalnya, tokoh Aku lebih menginginkan dihukum mati daripada hukuman kerja paksa seumur hidup. Namun, kebimbangan pun terjadi ketika ketakutan akan pelaksanaan hukuman mati serta keinginannya bersama Marie terus 
membayangi pikirannya. Beberapa kutipan berikut menggambarkan kegundahan tokoh Aku.

“-Ya, lanjutnya, aku belum tahu pernyataan mereka, tapi mungkin mereka mengesampingkan unsur "terencana", hingga jadi kerja paksa seumur hidup.

-Bapak ini bicara apa? Tukasku marah, seratus kali lebih baik mati!

Ya, mati!-Dan lagi, kudengar di dalam diriku sendiri, entah suara dari mana, apa yang kukhawatirkan untuk mengatakan hal itu? Bukankah hukuman mati hanya dijatuhkan di tengah malam saja, di bawah penerangan cahaya obor, di dalam ruangan suram dan gelap, dan di malam hujan serta di musim dingin?" (Hugo 2005: 7).

"Oh, putriku yang malang! Enam jam lagi, dan aku akan mati! Aku akan menjadi sesuatu yang menjijikan yang berserak di atas meja dingin di ruang-ruang kuliah. Sebuah kepala yang akan dicetak di satu sisi, dan tubuh yang akan dipotong-potong di sisi lain. Lalu sisanya akan dimasukkan ke dalam sebuah peti mati penuh, dan semuanya kemudian dikirim ke makam Clamart. Itu yang akan mereka lakukan terhadap ayahmu, orang-orang yang tidak satu pun membenciku ini, yang semua merasa iba terhadapku. Mereka akan membunuhku. Apa kamu bisa mengerti hal itu Marie?" (hlm. 62).

"Ah! Seandainya saja para juri itu melihatnya, melihat Marie mungilku! Mereka pasti akan mengerti bahwa ayah seorang anak yang berumur tiga tahun itu tidak boleh dibunuh." (hlm. 63).

"Oh, grasiku! Grasiku! Barangkali aku mendapat grasi. Raja tidak marah kepadaku. Panggilkan pembelaku! Pembelaku, cepat! Aku bersedia dihukum kerja paksa, dan habis urusan,-atau dua puluh tahun - atau selamanya dengan besi membara. Tapi tolong, ampuni hidupku!" (hlm. 65).
“Oh, kasihanilah aku! Satu menit lagi untuk menunggu grasiku! Kalau tidak aku akan melawan! Aku akan menggigit!” (hlm. 100).

Pergulatan mengenai wacana kebebasan dalam novel yang direpresentasikan melalui tokoh Aku menunjukkan bahwa hasrat kebebasan merupakan konstruksi. Wacana yang dipraktikkan dalam penceritaan menolak adanya pusat atau titik tolak pemikiran. Perdebatan kehendak bebas manusia dinegasikan oleh konsep atau sistem yang menentukan manusia dalam teks yang telah ditentukan. Sistem dalam hal ini, keluarga tokoh Aku dan pemerintah, merupakan institusi yang mengkonstruksi pemikiran tokoh Aku mengenai kebebasan. Konteks kebebasan tidak terlepas dari konsep kekuasaan. Oleh sebab itu, makna bahasa harus dilihat dalam satu kesatuan yang utuh, yakni dikaitkan dengan konteks dan situasi. Melalui wacana, bahasa mengungkapkan kedalaman ontologis dari pengalaman dan keberadaan manusia.

Tokoh Aku tidak dapat dengan mudah memutuskan nasibnya karena terkait dengan institusi yang diceritakan dalam novel. Pemerintah dengan sistem hukumnya telah mengatur jalannya peradilan. Keputusan yang telah ditetapkan menunjukkan kuasa wacana dalam institusi pemerintah. Tarung wacana pun kemudian terjadi, antara institusi keluarga dan institusi pemerintah. Tokoh Aku mengalami kebimbangan ketika berhadapan dengan pilihan, ingin tetap melihat Marie tubuh dewasa atau menjalani hukuman mati.

Dalam penceritaan di dalam novel, berbagai usaha dilakukan tokoh aku untuk dapat menghindari hukuman mati. Dari mencoba kabur dengan mengelabui penjaga penjara untuk dapat menukar baju tahanan dengan baju penjaga, naik banding untuk meminta garasi, hingga mencoba melakukan perlawanan kepada algojo eksekusi, kesemuanya itu sia-sia belaka. Usaha tokoh Aku seakan-akan tidak berarti. Tokoh Aku pada akhir penceritaan dimatikan oleh pengarangnya. Kebebasan yang begitu diinginkan tokoh Aku terkalahkan oleh kuasa wacana pengarang. 


\section{Aspek-aspek Kekuasaan dalam Le dernier jour d'un condamné}

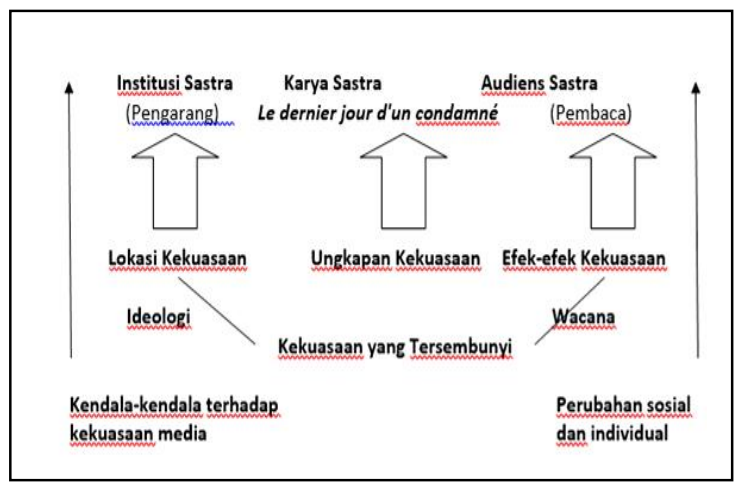

Melalui konsep kebebasan yang melingkupi penceritaan tokoh Aku, dapat digambarkan kaitan antara karya sastra dan aspek-aspek kekuasaan yang melingkupinya. Konsep penggambaran "Aspekaspek Kekuasaan dalam Le dernier jour d'un condamné" merupakan ilustrasi dari penulis dengan mengacu kepada bagan media dan aspek-aspek kekuasaan dalam Pengantar Untuk Memahami: Media dan Budaya Populer (Burton 2008: 75).Di dalam penggambaran aspek-aspek kekuasaan, peneliti memaparkan konsep kekuasaan yang tersembunyi sebagai bentuk transfer ideologi yang dilakukan pengarang kepada pembaca. Pertarungan wacana yang terjadi dalam pembacaan menunjukkan pengetahuan yang berbeda dari pembaca. Dengan begitu, efek kekuasaan yang tersembunyi-sebagai ekspresi dari ungkapan kekuasaan karya sastra-dapat tergambarkan melalui peleburan cakrawala historisitas pembaca dengan cakrawala teks.

Efek-efek kekuasaan di dalam novel terjadi karena adanya dialog teks dengan pembaca. Konsep dialogis sebagai ciri khas wacana diperlihatkan oleh cara komunikasi yang dipaparkan tokoh Aku dalam novel. Tokoh Aku mencoba berdialog dengan pembaca melalui tuturan kata yang terungkap dalam penceritaan. Teks seakan berbicara dengan pembacanya dan berusaha mengungkapkan jeritan batin melalui berbagai ungkapan, seperti pertanyaan-pertanyaan yang dilancarkan tokoh Aku. Kutipan berikut ini merupakan contoh usaha dialog yang dilakukan tokoh Aku dalam penceritaan.
"Dihukum mati! Eh, kenapa tidak? Semua orang telah dijatuhi hukuman mati dengan penangguhan yang tidak ditentukan, demikian kuingat telah membacanya di sebuah buku yang judulnya aku lupa dan hanya itu saja isinya yang bagus. Jadi apa bedanya dengan keadaanku sekarang?" (hlm. 9).

"Aku berkata pada diriku sendiri:

-Sekarang semua keperluan untuk menulis telah tersedia, kenapa aku tidak melakukannya? Tapi apa yang akan kutulis? Terkungkung di antara empat tembok batu dingin tanpa hiasan apa pun, tanpa kebebasan melangkah, tanpa cakrawala yang bisa kupandang, dan peklipur lara satusatunya hanyalah menyibukkan diri tanpa berpikir mengikutipantulan cahaya yang masuk melewati lubang pintu sel..." (hlm. 12-13).

"Mudah-mudahan yang kutulis di sini suatu hari nanti dapat berguna bagi orang lain, bisa mencegah hakim yang siap menghakimi, bisa menyelamatkan orangorang yang kurang beruntung dari sekarat yang kualami, baik ia bersalah maupun tidak. Mengapa? Apa gunanya? Apa pentingnya? Saat kepalaku telah terpancung, apa bedanya bagiku bila orang memenggal kepala-kepala lainnya? Apakah aku bisa memikirkan kegilaan ini?" (hlm. 15). "Oh, seandainya aku melarikan diri, betapa aku akan berlari melintasi ladang-ladang! Tidak jangan berlari. Itu akan menarik perhatian dan menimbulkan kecurigaan. Sebaliknya, aku berjalan pelan-pelan, kepala tegak, sambil bernyanyi." (hlm. 41-42).

Berbagai untaian kata yang menggambarkan kegelisahan tokoh Aku seakan membentuk dialog antara teks dan pembacanya. Tokoh Aku mengungkapkan carut-marut kebimbangan pemikirannya akan kebebasan dengan menyajikan teks-teks yang berusaha melakukan 
tanya-jawab. Dalam hal ini, pembaca sastra diajak untuk turut mengambil bagian dalam pergulatan pemikiran tokoh Aku mengenai kebebasan dirinya. Tarung makna wacana kebebasan yang bergulat dalam pemikiran menjadi syarat terbentuknya dialog antara pembaca dan teks. Oleh karena itu, dialogis membuatnya bersifat sosial (pembaca membawa muatan pengetahuan dan teks memuat ideologi tertentu) sehingga wacana tidak terisolasi.

Dengan mengacu kepada struktur dialogis wacana novelistik, maka ide mengenai kebebasan yang dikumandangkan tokoh Aku memberikan suatu tafsiran. Kebebasan tokoh Aku merupakan wujud perlawanan pengarang terhadap kerja paksa dan kebijakan pemerintah mengenai hukuman mati. Konteks tersebut terkait dengan represi pemerintah pada saat pengarang menciptakan karyanya. Berdasarkan penelusuran historis, novel Hari Terakhir Seorang Terpidana Mati merupakan wujud kritik sosial yang dilancarkan Hugo kepada represi pemerintah. Hugo memiliki ketertarikan kepada permasalahan sosial (Bach 1957). Melalui kuasa wacana dan dialogis, maka diperoleh ide-ide kebebasan sebagai kritik sosial pengarang terhadap represi yang dilancarkan pemerintah pada masanya. Kerja paksa dan kebijakan pemerintah mengenai hukuman mati adalah hal yang ditentang. Hal tersebut terlihat melalui penelusuran kekuasaan pada wacana dan dialog yang dibangun antara teks dan pembaca (peneliti sastra).

\section{SIMPULAN}

Konsep kuasa wacana dan dialogis yang dipaparkan oleh peneliti untuk mengkaji ide tersembunyi dalam novel Le dernier jour d'un condamné 'Hari Terakhir Seorang Terpidana Mati' mengacu kepada ide kebebasan yang merupakan kritik sosial pengarang. Berdasarkan konsep kuasa wacana, tokoh Aku tidak dapat lepas dari jeruji kekuasaan hukaman mati. Pada awal penceritaan, wacana pemberontakan terhadap hukuman kerja paksa seumur hidup dikumandangkan tokoh Aku, namun dalam perjalanan kisah selanjutnya tokoh Aku terbentur dengan institusi keluarga. Kebebasannya untuk memilih hukuman mati terbatasi oleh keinginan lainnya, yakni hasrat (kekuasaan) untuk melihat putrinya (Marie).

Jejaring kekuasaan-dalam penceritaan noveltidak dapat membebaskan keinginan tokoh Aku, institusi pemerintah sebagai pemegang kebijakan hukum menjadikan tokoh Aku tidak dapat terlepas dari keputusan hukuman mati. Pengarang, sebagai sang tiran dalam penciptaan novel, pada akhir penceritaan mematikan tokoh Aku. Dialog yang dipaparkan tokoh Aku menunjukkan perlawanan pengarang kepada represi pemerintah. Hal tersebut dapat ditelusuri melalui historisitas karya sastra. Dengan demikian, kritik sosial yang dilancarkan pengarang mengenai kebebasan merupakan "ide tersembunyi" yang didapat dengan membongkar kuasa wacana dan dialogis yang terjadi antara teks dan pembacanya.

\section{DAFTAR PUSTAKA}

Bach, Max. 1957. “Hugo's Interest in Social Problems", Modern Languages Notes. The johns Hopkins University Press.

Bakhtin, Mikhail. 1999. Problems of Dostoevsky's Poetics. Trans. Caryl Emerson. London, Minneapolis: University of Minnesota Press.

Barnett, Marva A. 2010. Victor Hugo on Things That Matter. New Haven: Yale University.

Blackmore, A.M. 2004. The Essential Victor Hugo. New York: Oxford University Press.

Burton, Graeme. 2008. Pengantar untuk Memahami: Media dan Budaya Populer. Yogyakarta: Jalasutra.

Foucault, Michel. 1998. The Will to Knowledge, The History of Sexuality: Volume 1. Trans. Robert Hurley. London: Penguin Books.

Gardiner, Michael. 1992. The Dialogics of Critique: M.M. Bakhtin and the Theory of Ideology. London and New York: Routledge.

Holquist, Michael. 2002. Dialogism: Bakhtin and his World. London and New York: Routledge.

Hugo, Victor. 2005. Hari Terakhir Seorang Terpidana Mati (Le dernier jour d'un condamné). Trans. M. Lady Lesmana. Jakarta: Enrique. 
O'Farrell, Clare. 2005. Michel Foucault. London, Thousand Oaks, New Delhi: Sage Publications.

Selden, Raman,. and Peter Widdowson. 1993. A Reader's Guide to Contemporary Literary Theory. New York: Harvester wheatsheaf.

Shirkhani, Fatemeh., dkk. 2015. "Bakhtinian Dialogic Concept in Language Learning Process". Procedia - Social and Behavioral Sciences, 510-515.

Dr. Hendra Kaprisma, S.Hum. adalah pengajar di Program Studi Rusia Fakultas IImu Pengetahuan Budaya Universitas Indonesia (FIB UI). Dia menyelesaikan S3 Program Studi Ilmu Susastra FIB UI dengan jalur khusus-tanpa menempuh jenjang S2-pada tahun 2015. Dia memulai kuliah S3 pada tahun 2009 dengan mengambil beberapa mata kuliah S2 tanpa tesis. Pada tahun 2011 dia mengikuti Sandwich Ph.D. Candidates di Universitas Negeri Saint-Petersburg, Rusia. Setahun kemudian (2012), dia kembali lagi ke Rusia untuk penelitian disertasi dengan mendapatkan penghargaan Sylff Research Award dari Tokyo Foundation. 